\title{
Therapeutic Programs for Students with Behavior Disorders in Public Schools
}

\author{
Nai-Cheng Kuo (Corresponding author) \\ Department of Teaching and Leading, Augusta University \\ 2500 Walton Way, Augusta, Georgia 30904, USA \\ E-mail: nkuo@augusta.edu
}

Received: December 20, 2016 Accepted: January 21, 2017 Published: January 23, 2017

doi:10.5296/jei.v3i1.10483 URL: http://dx.doi.org/10.5296/jei.v3i1.10483

\begin{abstract}
The Department of Justice has a responsibility to ensure that all programs serving students with emotional and behavioral disorders (EBD) abide by laws, as do state governments. This study took a close look at a Department of Justice's investigation of the appropriateness of a behavior intervention program (that is, the Georgia Network for Educational and Therapeutic Support; GNETS) and how the state government responded to inquiries. This study further explored how students with behavior disorders learned in a GNETS Program and what their progress was within an assessment and across assessments. Due to the fact that government-funded therapeutic services typically are more cost-efficient than private therapeutic services and may prevent students from being placed in residential or more restrictive placements, this study will help improve not just the services of GNETS programs but also the services of related programs for students with EBD in public school settings.
\end{abstract}

Keywords: Georgia Network for Educational and Therapeutic Support (GNETS), Therapeutic programs, Behavior intervention, Emotional and Behavior Disorders (EBD)

\section{Introduction}

Factors associated with behavioral disorders vary. One important fact that is often overlooked is traumatization. Trauma resulting from experiences like substance abuse, murder or accidental death in the family, and other violence creates self-helplessness in these students and affects their development in all aspects. These experiences overwhelm students' ability to cope, and they might develop perceptions such as "I'm a bad kid," "it's all my fault," "is something wrong with me?" and "no one understands me" (National Child Traumatic Stress Network, 2016). These students often struggle academically, emotionally, behaviorally, and socially when their perception of themselves, people, and the environment around them is 
passive or negative. In order to address these concerns, the state of Georgia has funded Georgia Network of Educational and Therapeutic Support (GNETS) programs since the 1970s to provide comprehensive and direct therapeutic services to students with emotional and behavioral disorders (EBD) particularly resulting from trauma.

Although GNETS programs aim to support public school systems and align their services with the Individuals with Disabilities Education Acts (IDEA), in its recent investigation report, the U.S. Department of Justice (2015) argues that GNETS programs funded by the State of Georgia provide "opportunities to its students that are unequal to those provided to students throughout the State who are not in the GNETS Program" (p. 1). The U.S. Department of Justice (2015) urges that the state government and its educational agencies should take action to remediate the past violations and to align its policies and practices with the Americans with Disabilities Act (ADA). It is important to note that this letter focuses on students lacking equal opportunities to receive education in the regular environment and to participate in activities that non-GNETS students receive, such as electives and extracurricular activities. The letter neither addresses the characteristics and the needs of students have experienced substance abuse or violence, nor instructional services and curricula tailored to help these students resist re-traumatization. A year later, a responding letter on behalf of the Georgia Department of Education was published to clarify the GNETS Program's scope, services, and its improvement (Belinfante, 2016). While the responding letter emphasizes the significance and positive benefits of therapy for students with behavioral disorders, no data were provided to show students' progress in GNETS Programs. Because the responding letter does not clearly justify why this group of students need to receive an education in a separate environment and does not provide data about how these students are progressively placed in the general education setting, the Department of Justice finally filed a lawsuit against GNETS programs in August, 2016.

Due to the fact that students with EBD are the largest group, among all disabilities, which receives education in an alternative learning environment (U.S. Department of Education, 2016) and all students with disabilities are entitled to a free and appropriate public education (FAPE) under IDEA, it is important to learn how the U.S. Department of Justice evaluates the appropriateness of behavior support programs and why intensive behavioral support programs are needed for students with severe behavioral disorders. This will further help educators evaluate their own practices and the quality of their services to students with EBD. To achieve the goals, there were three research questions that guided this study: 1) What does the U.S. Department of Justice say about GNETS programs and how does the Georgia Department of Education respond to it? 2) How are the changes in students' behavior correlated with their performance in communication, socialization, and cognition domains? 3 ) What are behavior therapists' evaluations on these students' behavior before and after the 20 weeks of intervention?

\subsection{GNETS Programs}

Currently, GNETS is comprised of 24 programs which has a total of 540 classrooms in 121 public schools and served over 4,500 students with behavioral disorders (Georgia Department 
of Education, 2016). When multidisciplinary team members decide that a student needs a placement in a GNETS program, the placement must be written in the student's Individualized Education Programs (IEP). The student's local school then helps transfer the student's data to GNETS programs. Behavior therapists in the GNETS Program will work collaboratively with parents, local school personnel, and other community agencies to provide instructional services that are grounded in Common Core State Standards, research-based behavioral interventions, IEP goals and objectives, and progress monitoring (Georgia Department of Education, 2016).

The purpose of GNETS programs is to "prevent children from requiring residential or other more restrictive placements" (GNETS Rules and Regulations, 2015, p. 1) and to support the local school systems' continuum of services. The Individuals with Disabilities Education Act (IDEA) has made it clear that when multiple data sources have indicated that general education classrooms are not benefiting students, an alternative placement must then be considered (IDEA, 2014). The law permits programs like GNETS to serve students who cannot cope in the regular environment to ensure these students' educational rights. For students to be accepted by GNETS programs, local schools must abide by two criteria, both (a) and (b) listed below:

(a) An IEP team may consider in-class services by a GNETS program for a child with an emotional and behavioral disorder based upon documentation of the severity of the duration, frequency and intensity of one or more of the characteristics of the disability category of emotional and behavioral disorders (EBD). This documentation must include prior extension of less restrictive services and data which indicate such services have not enabled the child to benefit educationally. (b) For children receiving in-class services, local schools are actively involved and exit criteria are developed upon entry into the GNETS program (GNETS Rules and Regulations, 2015, p. 1).

Moreover, GNETS programs adopt the Trauma-Informed Care (TIC) approach to create a learning environment where students feel safe, trusted, respected, and empowered. This approach consists of four dimensions: 1) knowing the widespread impact of trauma on students' behavior, 2) recognizing signs and symptoms of trauma in students, 3) responding to students' behavior professionally, and 4) helping students resist re-traumatization (National Center for Trauma-Informed Care, 2016). Data from the Georgia Department of Audits and Accounts Performance Audit Operations (2010) show that GNETS programs have helped students improve their behavior so that they are able to be included in the general education settings partially or fully.

\section{Methods}

\subsection{Setting}

The present study was conducted in 2015-2016 in one of the 24 GNETS programs located in an urban school district and the majority of the students were culturally diverse. The program served sixteen students referred from five school counties for their behavioral disorders. Both Trauma-Informed Care (TIC) and Positive Behavior Interventions and Support (PBIS) 
approaches are utilized throughout the program. The program provides consultations and observations prior to referrals. A multidisciplinary team-involving parents, special and general education teachers, school district representatives, and specialists who are knowledgeable about the student-was formed to evaluate the effectiveness of current interventions that had been made to help students be successful in the general education settings and the benefits if students would be placed in the GNETS program.

\subsection{Participants}

All students in the GNETS program met the eligibility criteria for receiving special education services and had IEPs. They had documentation from the multidisciplinary team that indicated their education in the regular environment was not benefiting their learning. Thirteen out of the sixteen students participated in the present study after their parent signed the consent forms approved by the Institutional Review Board (IRB) board. Most of the students had been through different types of trauma in their lives including being physically or sexually abused, experiencing domestic violence, having sudden or violent loss of loved ones, being neglected, and so on. Table 1 summarizes the backgrounds of the students. The majority of the students were African Americans (85\%) and their IEPs indicate that they needed intensive, structured, and small-group instructional support to help them deal with interpersonal relationships, waiting turns, verbal and physical control, aggression, and/or escaping behaviors.

Table 1. A summary of the students' backgrounds

\begin{tabular}{|c|c|c|c|c|c|}
\hline & $\begin{array}{l}\text { Current } \\
\text { grade }\end{array}$ & Ethnicity & $\begin{array}{l}\text { For how long has } \\
\text { the student been } \\
\text { placed in the } \\
\text { GNET Program } \\
\text { (Till May, 2016) }\end{array}$ & $\begin{array}{l}\text { Exit the } \\
\text { program }\end{array}$ & IEP behavioral goals \\
\hline Child A-1 & 5 & Caucasian & 24 months & May, 2016 & Physical and verbal control \\
\hline Child A-2 & 4 & African American & 18 months & - & Physical and verbal aggression \\
\hline Child A-3 & 3 & African American & 4 months & - & Physical aggression \\
\hline Child A-4 & 4 & African American & 45 months & May, 2016 & $\begin{array}{l}\text { Interpersonal relationships } \\
\text { Verbal control }\end{array}$ \\
\hline Child A-5 & 5 & African American & 27 months & - & Interpersonal relationships \\
\hline Child A-6 & 3 & African American & 9 months & - & $\begin{array}{l}\text { Interpersonal relationships } \\
\text { Wait turns }\end{array}$ \\
\hline Child A-7 & 2 & African American & 4 months & - & Physical and verbal control \\
\hline Child A-8 & 3 & African American & 8 months & - & Physical control and aggression \\
\hline Child A-9 & 3 & African American & 27 months & - & Physical and verbal aggression \\
\hline
\end{tabular}




\begin{tabular}{|l|l|l|l|l|l|}
\hline Child A-11 & 3 & African American & 7 months & - & $\begin{array}{l}\text { Interpersonal relationships } \\
\text { Physical control } \\
\text { Elopement }\end{array}$ \\
\hline Child A-12 & 2 & African American & 6 months & - & $\begin{array}{l}\text { Physical and verbal control } \\
\text { Physical and verbal aggression }\end{array}$ \\
\hline Child A-15 & 4 & African American & 6 months & - & Physical and verbal aggression \\
\hline Child A-16 & 4 & Caucasian & 5 months & - & Physical and verbal aggression \\
\hline
\end{tabular}

Note. Students A-10, A-13, and A-14 did not participate in the present study due to their parents' willingness. The length when students stayed in the GNETS program did not include summer and winter break months. Furthermore, Child A-1 and Child A-4 met the exit criteria at the end of the spring semester in 2016 and were transferred back to the general education settings. The other students remained in the program.

\subsection{Data Collection and Analysis}

Both qualitative and quantitative data were collected. Qualitative data that help understand the central phenomena of GNETS programs include the government-issued operations manual, rules and regulations, and strategic plans. The letter of "Georgia Network for Educational and Therapeutic Support" from the U.S. Department of Justice and the responding letter from an attorney's office on behalf of the State of Georgia Department of Education were also collected. A coding process was used to analyze qualitative data, including reading through the data, coding data, reducing overlaps of codes, and collapsing codes into themes (Creswell, 2015).

Quantitative data consisting of students' performance on two measures were collected during the 20 weeks of the intervention. The first measure was the Developmental Therapy Objective Rating Form-Revised (DTORF-R). DTORF-R is "a criterion-referenced assessment instrument," which has 171 items hierarchically organized in four ordinal subscales: Behavior (Doing: 33 items), Communication (Saying: 35 items), Socialization (Relating: 41 items), and Cognition (Thinking: 62 items)" (Wood, Quirk, \& Swindle, 2006, p. 62). To help students in the GNETS program meet their IEP goals, the items selected for intervention were determined by multidisciplinary teams. The students' performance on DTORF-R was monitored at the beginning, in the middle, and at the end of the semesters. Detailed information about the competencies of each domain in the elementary school level is shown in Table 2. 


\section{Macrothink}

Table 2. Key competencies of each domain in the elementary school level

\begin{tabular}{|c|c|c|}
\hline Domain & Competency & \\
\hline Behavior & $\begin{array}{l}\text { - } \quad \text { Complete work independently } \\
\text { - } \quad \text { Understand rules and expectations } \\
\text { - } \quad \text { Regulate own behavior }\end{array}$ & $\begin{array}{l}\text { - } \text { Imitate positive behavioral role models } \\
\text { - } \quad \text { Use control when provoked } \\
\text { - } \quad \text { Accept responsibility for own behavior } \\
\text { - } \quad \text { Contribute to group solutions }\end{array}$ \\
\hline Communication & $\begin{array}{ll}\text { - } & \text { Describe experiences } \\
\text { - } & \text { Dialogue in groups } \\
\text { - } & \text { Express feelings of self and others }\end{array}$ & $\begin{array}{l}\text { - } \\
\text { - } \quad \text { Explain reactions of others } \\
\text { - } \quad \text { Initiate relationships } \\
\text { - } \quad \text { Support others }\end{array}$ \\
\hline Socialization & $\begin{array}{l}\text { - Cooperate with others } \\
\text { - Recognize basic values of right } \\
\text { and wrong } \\
\text { - } \quad \text { Value oneself }\end{array}$ & $\begin{array}{ll}\text { - } & \text { Become an accepted group member } \\
\text { - } & \text { Form friendships and a social self } \\
\text { - } & \text { Identify with adult heroes } \\
\text { - } & \text { Recognize others' opinions } \\
\text { - } & \text { Draw inferences from social situations }\end{array}$ \\
\hline Cognition & $\begin{array}{l}\text { - Explain actions and feelings of } \\
\text { fictional characters } \\
\text { - Write to communicate } \\
\text { - Develop game skills }\end{array}$ & 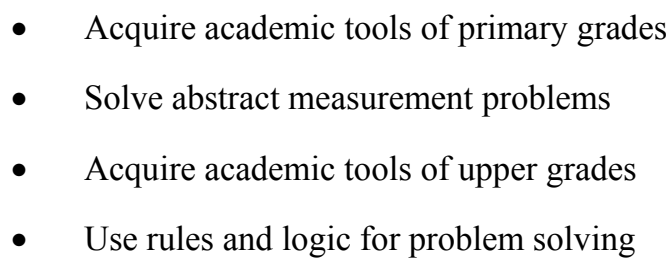 \\
\hline
\end{tabular}

Source: Wood, Quirk, and Swindle (2016). Teaching responsible behavior. Developmental therapy-developmental teaching for troubled children and adolescents. Austin, TX: PRO-ED.

The second measure was the Social Express, which is an animated app that helps students develop social-awareness skills, solve daily-life problems, learn hidden-rules, and navigate social situations through interactive video modeling. The topics of the animations include self-management (13 scenarios), group participation (2 scenarios), conversations (12 scenarios), attentive listening (5 scenarios), conflict resolution (6 scenarios), relationship management ( 2 scenarios), critical thinking (3 scenarios), non-verbal communication (2 scenarios), and review (1 scenario). During the 20 weeks of intervention, students were encouraged to watch the scenarios and complete questions after each scenario in their free time at home or in school. Some scenarios were selected for lecturing in a whole group by the students' behavior therapist. The numbers of the Social Express scenarios that students completed with $80 \%$ and above accuracy on the assessment questions were recorded. In addition, pre- and post-survey questionnaires completed by the behavior therapists in the 
GNETS program were collected. There were 20 survey questions in the survey questionnaires covering topics that students learned from the scenarios, which is shown in Table 3.

Table 3. Pre- and post-survey questionnaires

\begin{tabular}{|c|c|}
\hline \multicolumn{2}{|l|}{ Questions } \\
\hline 1. Working and playing well with others & 11. Making decisions for self \\
\hline 2. Listening attentively & 12. Expressing compliments to others \\
\hline 3. Respecting his/her own property & 13. Making friends easily \\
\hline 4. Following rules of the classroom/school & 14. Working constructively as a group member \\
\hline 5. Assuming appropriate level of responsibility & 15. Interpreting body language effectively \\
\hline 6. Showing consideration for others & 16. Accomplishing tasks on his/her own \\
\hline 7. Showing self-control & 17. Compromising/negotiating effectively \\
\hline 8. Asking for help in an appropriate way & 18. Taking turns in conversation \\
\hline 9. Offering help to others & 19. Demonstrating appropriate hygiene \\
\hline 10. Expressing anger appropriately & 20. Taking ownership for mistakes made \\
\hline
\end{tabular}

Source: The Social Express at http://thesocialexpress.com/

Descriptive statistics and the coefficient of multiple correlations were used to analyze quantitative data. The descriptive statistics data show a summary of the overall trends in data and the coefficient of multiple correlation data explore the correlations of students' performance across different domains in an assessment and their performance across different assessments. Two behavior therapists' agreement on the survey questionnaires was reported.

\section{Results}

\subsection{The U.S. Department of Justice Challenges the Georgia Department of Education over GNETS Programs}

The U.S. Department of Justice is one of the federal agencies that enforces the ADA and ensures that public accommodations and state and local government services abide by the ADA regulations. Despite other issues like the condition of facilities noticed in the letter of the U.S. Department of Justice to the Georgia Department of Education, segregation-related words such as "separate," "segregated," or "discriminative" are mentioned over 90 times by the U.S. Department of Justice. Apparently, the U.S. Department of Justice is concerned that GNETS programs have violated ADA and discriminated against people with disabilities. 
Major issues found in the letter of the U.S. Department of Justice include: 1) the state government permits segregated educational services provided by GNETS programs; 2) students in GNETS programs do not have an equal access to educational opportunities that non-GNETS students do; and 3) students with emotional and behavior disorders (EBD) can be accommodated in general educational settings (U.S. Department of Justice, 2015).

In responding to the concerns of the U.S. Department of Justice, the state government does not explain why students in GNETS programs need to be placed in a separate learning environment. Instead, the Georgia Department of Education (DOE) addresses three concerns. First, the Georgia DOE does not have a direct operational authority to GNETS programs and thus does not administer GNETS services. Second, the state government will continue assisting the improvement of GNETS services in both regular classrooms and self-contained classrooms, will ensure that teachers in GNETS programs are highly-qualified and their students take standardized assessments like their peers in non-GNETS settings. Third, the Georgia DOE will review necessary data to examine which students might be able to return to general educational settings. This will include a review of the individualized education programs (IEPs) under the requirement of the Individuals with Disabilities Education Act (IDEA). In addition, the Georgia DOE will overhaul the poor conditions of school facilities and move some programs to better locations. Table 4 compares and contrasts the major issues addressed in the letter from the U.S. Department of Justice and the responses from the Georgia Department of Education.

Table 4. Key issues address by the U.S. Department of Justice and Georgia Department of Education

\begin{tabular}{|c|c|}
\hline U.S. Depa & Georgia Department of Education (2016) \\
\hline $\begin{array}{l}\text { Major Issue 1. The state government permits } \\
\text { segregated educational services provided by } \\
\text { GNETS programs. } \\
\text { - "A majority of students in the GNETS program } \\
\text { receive services in segregated settings" (p. 8). } \\
\text { - "The state unnecessarily relies on segregated } \\
\text { placements within the GNETS program to serve } \\
\text { students with behavior-related disabilities" (p. 10). } \\
\text { - "Most students in the GNETS program could } \\
\text { be served in more integrated settings and would not } \\
\text { oppose more integrated services" (p. 11). } \\
\text { - "The state administers its GNETS services in a } \\
\text { way that unnecessarily segregates students with } \\
\text { behavior-related disabilities and puts other such } \\
\text { students at serious risk of unnecessary segregation" }\end{array}$ & $\begin{array}{l}\text { Major Response 1. The Georgia Department of } \\
\text { Education does not directly administer GNETS } \\
\text { programs. } \\
\text { - "The Georgia Department of Education (GDOE) } \\
\text { lacks significant operational control over the GNETS } \\
\text { program...local school systems are statutorily } \\
\text { empowered and charged with providing special } \\
\text { educational programs" (p. 2). } \\
\text { "The GDOE does not have direct control over } \\
\text { how a particular GNETS program is managed" (p. 2). } \\
\text { Major Response 2. Teachers in GNETS programs } \\
\text { are highly-qualified and students need to take } \\
\text { standardized assessments like their peers in } \\
\text { non-GNETS settings. }\end{array}$ \\
\hline
\end{tabular}


(p. 12)

Major Issue 2. Students in GNETS do not receive equal education that Non-GNETS students do.

- "The state does not offer students in the GNETS program equal opportunities to participate in elective courses or extracurricular activities" ( $p$. 15).

- “The GNETS program's facilities and learning environments are unequal to those of other settings" (p. 16).

- "The state does not provide students in the GNETS program equal opportunities to participate in the instructional services and curriculum received by non-GNETS students" (p. 17).

Major Issue 3. Students with EBD can be accommodated in general educational settings.

- Georgia "can reasonably modify its programs, redeploy human capital, and use available funds to similarly provide and coordinate services for students currently in the GNETS Programs to enable them to be appropriately educated and served in their home general education schools." (p. 19)
- "While [Teacher Keys Evaluation System] TKES applies to all Georgia educators, GDOE has determined that the program can be better tailored to address the particular needs of GNETS program educators" (p. 5).

- "The GOE has also implemented i-Ready K-12 Diagnostic and K-8 reading and mathematics programs for all GNETS students" (p. 5).

Major Responding 3. The state government is reviewing necessary data to return students to general educational settings and to improve current services.

- $\quad$ "A review of every IEP for all students currently enrolled in a GNETS program is underway...to better GDOE's understanding of the facts on the ground and ability to return students who may be served in a general educational setting" (p 5).

- "The State is dedicated to including community supports and service providers to enhance GNETS program services provided in the general education environment and/or in self-contained settings" (pp. 5-6).

- "GDOE hired an architectural firm to inspect each GNETS facility and make recommendations regarding any necessary structural improvements" (p. 1).

\subsection{The Correlations of Students' Performance in Behavior, Communication, Socialization, and Cognition Domains}

Students' progress was monitored before, during, and after the semester. After the 20 weeks of intervention in the GNETS program, students increased $4 \%$ and $16 \%$ of scores across behavior, communication, socialization, and cognition domains in DTORF-R. The calculation formula was:

$$
\frac{\text { End of semester score }- \text { Beginning of semester score }}{\text { Beginning of Semester Score }} \times 100 \%
$$

The DTORF-R data also indicate that students were making progress toward their grade levels. Their objectives mastered at the end of the semester were between $72 \%$ and $88 \%$ of the grade levels. Some students had missing data in DTORF-R because when they entered the program, the assessment periods were over. Students who entered the program in the middle 
of the semester would not have beginning-of-the-semester scores, and students who entered the program after the middle of the semester would not have both beginning-of-the-semester scores and middle-of-the-semester scores. Table 5 shows a summary of students' performance on DTORF-R. It is important to note that DTORF-R was only one of the assessments used in the GNETS program.

Table 5. Progress monitoring data - DTORT-R

\begin{tabular}{|c|c|c|c|c|c|c|c|c|c|c|c|c|c|}
\hline & \multicolumn{3}{|c|}{$\begin{array}{l}\text { DTORF } \\
\text { Behavior }\end{array}$} & \multicolumn{3}{|c|}{$\begin{array}{l}\text { DTORF } \\
\text { Communication }\end{array}$} & \multicolumn{3}{|c|}{$\begin{array}{l}\text { DTORF } \\
\text { Socialization }\end{array}$} & \multicolumn{3}{|c|}{$\begin{array}{l}\text { DTORF } \\
\text { Cognition }\end{array}$} & \multirow{2}{*}{$\begin{array}{l}\text { Current } \\
\text { Objectives } \\
\text { Mastered as\% } \\
\text { of Expected } \\
\text { Score }\end{array}$} \\
\hline & B & M & E & B & $\mathrm{M}$ & $\mathrm{E}$ & B & M & E & B & M & E & \\
\hline Child A-1 & 19 & 22 & 23 & 18 & 21 & 23 & 24 & 23 & 23 & 44 & 44 & 45 & $88 \%$ \\
\hline Child A-2 & 11 & 11 & 13 & 17 & 15 & 15 & 16 & 17 & 20 & 41 & 38 & 40 & $76 \%$ \\
\hline Child A-3 & $\mathrm{n} / \mathrm{a}$ & 12 & 14 & $\mathrm{n} / \mathrm{a}$ & 12 & 13 & $\mathrm{n} / \mathrm{a}$ & 18 & 18 & $\mathrm{n} / \mathrm{a}$ & 38 & 38 & $72 \%$ \\
\hline Child A-4 & 16 & 19 & 22 & 17 & 19 & 18 & 22 & 22 & 23 & 37 & 37 & 37 & $74 \%$ \\
\hline Child A-5 & 19 & 19 & 21 & 19 & 21 & 21 & 22 & 23 & 23 & 43 & 43 & 44 & $78 \%$ \\
\hline Child A-6 & 7 & 7 & 8 & 12 & 14 & 16 & 15 & 14 & 14 & 39 & 39 & 39 & $78 \%$ \\
\hline Child A-7 & $\mathrm{n} / \mathrm{a}$ & 11 & 13 & $\mathrm{n} / \mathrm{a}$ & 15 & 16 & $\mathrm{n} / \mathrm{a}$ & 13 & 15 & $\mathrm{n} / \mathrm{a}$ & 43 & 43 & $84 \%$ \\
\hline Child A-8 & 14 & 11 & 22 & 11 & 11 & 21 & 13 & 14 & 32 & 33 & 36 & 49 & $88 \%$ \\
\hline Child A-9 & 14 & 17 & 16 & 16 & 16 & 17 & 17 & 18 & 19 & 35 & 36 & 37 & $77 \%$ \\
\hline Child A-11 & 10 & 10 & 13 & 15 & 17 & 16 & 18 & 17 & 19 & 37 & 39 & 39 & $76 \%$ \\
\hline Child A-12 & $\mathrm{n} / \mathrm{a}$ & 8 & 10 & $\mathrm{n} / \mathrm{a}$ & 15 & 15 & $\mathrm{n} / \mathrm{a}$ & 12 & 13 & $\mathrm{n} / \mathrm{a}$ & 37 & 37 & $72 \%$ \\
\hline Child A-15 & $\mathrm{n} / \mathrm{a}$ & $\mathrm{n} / \mathrm{a}$ & 14 & $\mathrm{n} / \mathrm{a}$ & $\mathrm{n} / \mathrm{a}$ & 15 & $\mathrm{n} / \mathrm{a}$ & $\mathrm{n} / \mathrm{a}$ & 20 & $\mathrm{n} / \mathrm{a}$ & $\mathrm{n} / \mathrm{a}$ & 39 & $75 \%$ \\
\hline Child A-16 & $\mathrm{n} / \mathrm{a}$ & $\mathrm{n} / \mathrm{a}$ & 16 & $\mathrm{n} / \mathrm{a}$ & $\mathrm{n} / \mathrm{a}$ & 15 & $\mathrm{n} / \mathrm{a}$ & $\mathrm{n} / \mathrm{a}$ & 20 & $\mathrm{n} / \mathrm{a}$ & $\mathrm{n} / \mathrm{a}$ & 41 & $73 \%$ \\
\hline
\end{tabular}

Note. B (beginning of the semester), M (middle of the semester), and E (end of the semester). Students A-10, A-13, and A-14 did not participate in the present study due to their parents' willingness.

Although students in the GNETS program needed to learn all content areas like non-GNETS students, the program added behavior therapy to its curriculum to help students improve behavior. A multiple correlation coefficient analysis was conducted to evaluate how students' performance in the behavior domain was related to their performance in the other domains. Table 6 shows that students' performance in the behavior domain had a very strong correlation with their performance in communication and socialization domains $(r \geq 80)$ and 
had a moderate correlation with their cognition skills.

Table 6. Multiple correlations of students' performance across domains

\begin{tabular}{|l|l|l|l|l|}
\hline & Behavior & Communication & Socialization & Cognition \\
\hline Behavior & 1 & & & \\
\hline Communication & 0.80 & 1 & & \\
\hline Socialization & 0.84 & 0.67 & 1 & \\
\hline Cognition & 0.56 & 0.71 & 0.68 & 1 \\
\hline
\end{tabular}

\subsection{The Behavior Therapists' Evaluations of Students' Performance}

The Social Express progress monitoring data (see Table 7) indicate that each student completed different numbers of scenarios at their own pace throughout the semester. Two behavior therapists (one was the classroom teacher of the students and the other one was the program director who supervised the intervention) completed the pre-survey questionnaires at the beginning of the semester and post-survey questionnaires at the end of the semester. After completing the questionnaires, the two behavior therapists checked their evaluations with each other. Disagreements were resolved through multiple discussions and revisiting students' performance data until both of them reached $100 \%$ of agreement. The evaluation data indicate that only three of the students displayed proper behavior stably and consistently as defined by the therapists (i.e., Children A-1, A-4, A-5, and A-8).

Table 7. Progress monitoring data - the Social Express

\begin{tabular}{|l|l|l|l|}
\hline & $\begin{array}{l}\text { Number of } \\
\text { scenarios completed }\end{array}$ & $\begin{array}{l}\text { Does the student generally } \\
\text { display proper behavior? } \\
\text { (Pre-Survey) }\end{array}$ & $\begin{array}{l}\text { Does the student generally } \\
\text { display proper behavior? } \\
\text { (Post-Survey) }\end{array}$ \\
\hline Child A-1 & 20 & $100 \%$ & $100 \%$ \\
\hline Child A-2 & 20 & $5 \%$ & $15 \%$ \\
\hline Child A-3 & 11 & $30 \%$ & $20 \%$ \\
\hline Child A-4 & 46 & $80 \%$ & $80 \%$ \\
\hline Child A-5 & 16 & $55 \%$ & $75 \%$ \\
\hline Child A-6 & 16 & $0 \%$ & $25 \%$ \\
\hline Child A-7 & 16 & $15 \%$ & $25 \%$ \\
\hline
\end{tabular}




\begin{tabular}{|l|l|l|l|}
\hline Child A-8 & 26 & $40 \%$ & $60 \%$ \\
\hline Child A-9 & 10 & $10 \%$ & $10 \%$ \\
\hline Child A-11 & 19 & $20 \%$ & $40 \%$ \\
\hline Child A-12 & 23 & $5 \%$ & $15 \%$ \\
\hline Child A-15 & 23 & $15 \%$ & $10 \%$ \\
\hline Child A-16 & 9 & $45 \%$ & $45 \%$ \\
\hline
\end{tabular}

Note. There are 20 survey questions in the questionnaires covering topics that students learned from the scenarios: 1) working and playing well with others, 2) listening attentively, 3) respecting his/her own property, 4) following rules of the classroom/school, 5) assuming appropriate level of responsibility, 6) showing consideration for others, 7) showing self-control, 8) asking for help in an appropriate way, 9) offering help to others, 10) expressing anger appropriately, 11) making decisions for self, 12) expressing compliments to others, 13) making friends easily, 14) working constructively as a group member, 15) interpreting body language effectively, 16) accomplishing tasks on his/her own, 17) compromising/negotiating effectively, 18) taking turns in conversation, 19) demonstrating appropriate hygiene, 20) taking ownership for mistakes made (Social Express, 2016).

The correlation coefficient of DTORF-R and the Social Express shows that the number of the Social Express scenarios that students completed has a small positive correlation with their DTORF-R overall performance $(r<.01)$. However, the number of the Social Express scenarios have a very high positive correlation with the behavior therapists' evaluation of students' behavior $(r>.90)$. In other words, the more Social Express scenarios the students completed, the higher the scores they received on the pre- and post-survey questionnaires embedded in the Social Express from behavior therapists. This is likely because the pre- and post-survey questionnaires were pertinent to the Social Express scenarios.

\section{Discussions}

\subsection{ADA vs. IDEA}

The U.S. Department of Justice investigated GNETS programs and argued that the programs provide discriminative and separate education for students with EBD based on the ADA and its regulations. The ADA signed into law in the 1990s is the first comprehensive civil rights law that "prohibits discrimination against individuals with disabilities in all areas of public life, including jobs, schools, transportation, and all public and private places that are open to the general public" (The ADA National Network, 2016). To make sure that students with EBD have the same rights and educational opportunities as their peers without EBD, the U.S. Department of Justice carefully monitors behavior programs like GNETS. In contrast, the establishment of GNETS programs is grounded in the IDEA. Unlike the ADA, the IDEA is an education law that governs how states and public agencies serve eligible infants, toddlers, 
children and youth with disabilities between birth and 21 years old (IDEA, 2004). While the IDEA does not specify the alternative educational setting in which instructional services must be provided, the IDEA is clear that "the determination of an appropriate alternative educational setting must be selected" by a multidisciplinary team to enable students to progress toward their IEP goals (IDEA, 2004). The IDEA also states that what constitutes an appropriate alternative educational setting will depend on the conditions and circumstances in each individual case. By law, a student who is eligible for special education services must have an IEP developed by a multidisciplinary team. The team consists of the parents of the students, general and special education teachers, school district representatives, and specialists who are knowledgeable about the students. Therefore, the judgment about the appropriateness of placing students in GNETS programs should be based on the multidisciplinary team's data, not some social norm regarding the culturally entrenched idea of educational segregation. There's a lot of social "baggage" that comes with the idea of "segregation in schools" that is more to do with this country's issues with race relations and inequity and unrelated to the issue of whether students who have EBD are getting the support they need in or out of the general classroom. Non-discriminative education does not mean that all students should learn the same things in the same environment. Rather, it means that students receive an education that is equally helpful to them and equally valued by them and their parents.

Although electives and extracurricular activities in general education, as pointed out by the U.S. Department of Justice, are equally important to students in GNETS programs, students with severe behavioral disorders need trained personnel who understand the factors associated with their behavior and who help them develop proper behavior. Particularly for students who have experienced sexual assault or abuse as well as other extreme violence in their lives, it is necessary to start from small steps before placing them in a general learning setting where it is often non-structured and unpredictable. Perry and Pollard (1998) argue that only by defining and using child-specific and developmentally-informed models to guide educational and therapeutic supports can children gradually resist re-traumatization and lead normal lives.

It is a laudable effort that GNETS programs adopt Trauma-Informed Care (TIC) and Positive Behavior Intervention and Support (PBIS) to work with their students. To reduce ambiguity, the programs should make their instructional activities and students' performance data transparent and accessible like non-GNETS students. One way to achieve this goal is to enhance the programs' websites to allow people to better understand what instructional activities, services, and events are provided as well as their students' achievement inside and outside the programs. Moreover, because GNETS programs are part of the public school system, the state government does have the responsibility to help improve the quality of the programs and to ensure that the programs are aligned with the ADA, IDEA, and other laws and regulations.

\subsection{Academic Performance of Students with Behavioral Disorders}

This study further examined GNETS students' performance in the behavior, communication, 
socialization, and cognition domains. The results are consistent with previous studies that have shown the positive relationships between students' behavior and their academic performance (Gunter \& Denny, 1996; Trout, Nordness, Pierce, \& Epstein, 2003; Wehby, Lane, $\&$ Falk, 2003). In the present study, all students made different degrees of progress at the end of the semester, not only in their behavior but also in their social and learning skills. However, the multiple correlation coefficient analysis indicates that the improvement of behavior competencies is highly correlated with their communication and socialization competencies, but is only moderately correlated with their cognition competences. In other words, these students still need instructional support tailored to meet their learning needs, such as writing, reading, rules and logic for problem solving, and mathematics. Although the curriculum of GNETS programs is developed based on Common Core State Standards, cognitive strategies (Graham, 2006; Pressley \& Harris, 2006) and executive control functions like attention, perception, rehearsal, organization, and elaboration (Raymond, 2016) can be included and taught explicitly to enhance students' cognition competencies.

\subsection{Bridging the Knowing-Doing Gap}

The Social Express scenarios seemed engaging and helpful to GNETS students. On average, students completed 20 scenarios with $80 \%$ and above accuracy on the assessment questions of each scenario. One of the students even completed 46 scenarios with $80 \%$ and above accuracy. However, the behavior therapists' evaluations on the students' behavior show that only four of the students exhibited proper behavior constantly and stably (Child A-1, Child A-4, Child A-5, and Child A-8). That is, most of the students still had not exhibited proper behavior constantly and stably. Therefore, there might be a gap between knowing and doing. Students watched the scenarios and answered scenario assessment questions correctly. However, they did not maintain or generalize the skills from the scenarios to their daily practices well. To help students maintain and generalize skills, Mercer, Jordan, and Miller (1994) suggest teachers: 1) help students develop motivation to learn and not just to complete a task, 2) hold periodic discussions throughout the instructional process, 3) provide students with a variety of examples and experiences, and 4) teach students to solve pertinent problems in their daily lives. Through a combination of research-validated instructional approaches and therapeutic support, traumatized students can restore their confidence, rebuild trust with people, accelerate cognitive development, and learn how to cope in the regular environment step by step.

\subsection{Summer Setback}

Although the multidisciplinary team had made a determination at the end of the semester to refer Child A-1 back to the general education setting, the student's parents contacted the GNETS program director and were considering sending him back to the GNETS program due to an incident occurring during the summer break. When the student was in a summer program where it was not well-structured and had a big group of students, the student lost his physical and verbal control and had fights with peers.

When working with traumatized students, it is important not to change these students' learning environment dramatically. Take Child A-1 as an example, during the regular 
semesters, behavior therapists could have created opportunities that helped him ease into the general education setting, building from one hour per day to two hours, to half a day, and finally whole days of inclusion. Inclusion time should increase reasonably based on how the student adjusted himself to the new environment. Placing a traumatized student in a non-structured, big-group, with untrained personnel can do harm to the student and to people around him/her.

It is recommended to place these students in a more structured, small-group, and mentoring program during summer. If such programs are not available in students' communities, GNETS programs can work with parents to reach out organizations like "Reach Out and Read" or "Reading is Fundamental" to create home libraries (Evans, Kelley, Sikora, \& Treiman, 2010) and to increase students' access to books. Parents can also take advantage of public library resources to help their children and learn with their children. In addition, GNETS programs can help parents identify high-quality and free expanded programs before the summer semester starts. With the support from school districts, extending school days is also a good option. Finally, research shows that having good mentoring partnerships can help students with cognitive, social, and behavioral development (Rhodes, 2005; Rhodes, 2008; Rhodes \& DuBois, 2008) and help them stay in school. GNETS programs can create opportunities to help their students find good mentors in school whom these students respect, trust, and are willing to be challenged by on negative views they hold.

\section{Conclusion}

The significance of the study is three-fold. First, it helps people understand how the Department of Justice evaluates the appropriateness of behavior intervention programs and how the program sponsor government responded to inquiries. The Department of Justice has a responsibility to ensure that all programs serving students with special needs abide by laws, as do state governments. Second, the study took a close look at how students with behavior disorders learned in the GNETS Program and what their progress was within an assessment and across assessments. Third, learning from GNETS programs can help other educators reflect on their own practice, summer support, as well as the quality and appropriateness of their behavioral services to students with behavior disorders.

The findings indicate that each student in the GNETS program learned and improved their behavior through the intensive intervention. However, ongoing instructional support must be provided to those who had not displayed proper behaviors stably and consistently. It is important that GNETS programs help people understand the characteristics and unique needs of students who have experienced violence in their lives. To avoid misunderstanding that GNETS programs provide unfair or discriminative education to their students, the programs' curriculum, instructional activities, events, as well as their students' achievement inside and outside the programs must be transparent and students' performance data need to be accessible for evaluation.

While the greater demand for educational services for students with severe behavioral disorders has justified the need for intensive and therapeutic support as well as the importance of the present study, there are limitations in the present study that need to be 
addressed. First, evaluating other assessment data in addition to DTORF-R, the Social Express, as well as behavior therapists' evaluations would be beneficial. However, given the fact that each GNETS program had a small number of students, revealing all assessment data in just one program could create a risk of participants being easily recognized or identified. To protect students' confidentiality and collect comprehensive data, future studies should expand their investigations to more or all GNETS programs. Second, the present study was only conducted in one of the 24 GNETS programs located in an urban school district that served students who were culturally diverse. The findings might not represent all GNETS programs. However, the study provides critical information from document analyses, direct assessments, and practitioners' experiences, which can provide a framework for future studies in this area.

Overall, the evaluations from the Department of Justice on GNETS programs and an in-depth examination of how a GNETS program served traumatized students are important and educational. Because government-funded therapeutic services typically are more cost-efficient than private therapeutic services, this study will help improve not just the services of GNETS programs but also the services of related programs for students with EBD in the U.S and elsewhere in the world.

\section{References}

Belinfante, J. (2016). Re: Georgia Network for Educational and Therapeutic Support. Robbins Litigation and Regulatory Law. Retrieved from https://www.gadoe.org/CurriculumInstruction-and-Assessment/Special-Education-Services/Documents/GNETS/2016-17/GaDO E's\%20Update\%20to\%20DOJ.pdf

Creswell, J. W. (2015). Educational research: Planning, conducting, and evaluating quantitative research. Upper Saddle River, NJ: Pearson.

Evans, M., Kelley, J., Sikora, J., \& Treiman, D. (2010). Family scholarly culture and educational success: Books and schooling in 27 nations. Research in Social Stratification and Mobility, 28, 171-197. https://doi.org/10.1016/j.rssm.2010.01.002

Georgia Department of Audits and Accounts Performance Audit Operations. (2010). Georgia Network for Educational and Therapeutic Support (GNETS). Retrieved from http://www.gahsc.org/nm/2010/educational\%20and\%20therapeutic\%20support\%20-\%20gnet s\%5B1\%5D.pdf

Georgia Department of Education. (2016). Georgia Network for Educational and Therapeutic Support. Retrieved from http://www.gadoe.org/Curriculum-Instruction-and-Assessment/Spe cial-Education-Services/Pages/Georgia-Network-for-Special-Education-and-Supports.aspx

GNETS Rules and Regulations. (2015). Georgia Network for Educational and Therapeutic Support (GNETS). Retrieved from http://archives.gadoe.org/_documents/doe/legalservices/ 160-4-7-.15.pdf

Graham, S. (2006). Strategy instruction and the teaching of writing: A meta-analysis. In C. MacArthur, S. Graham, \& J. Fitzgerald (Eds.), Handbook of writing research. New York: 
Guilford Press.

Gunter, P. L., \& Denny, R. K. (1996). Research issues and needs regarding teachers' use of classroom management strategies. Behavioral Disorders, 22, 15-20.

IDEA. (2004). Individuals with Disabilities Education Improvement Act. Public Law (pp. 108-446).

Mercer, C. D., Jordan, L., \& Miller, S. P. (1994). Implications of constructivism for teaching math to students with moderate to mild disabilities. The Journal of Special Education, 28(3), 290-306.

National Child Traumatic Stress Network. (2016). What is child traumatic stress? Retrieved from http://www.nctsn.org/resources/audiences/parents-caregivers/what-is-cts

Pressley, M., \& Harris, K. (2006). Cognitive strategies instruction: From basic research to classroom instruction. In P. Alexander \& P. Winne (Eds.), Handbook of educational psychology (2nd ed., pp. 265-286). Mahwah, NJ: Erlbaum.

Raymond, E. B. (2016). Learners with mild disabilities: A characteristics approach (5th ed.). Upper Saddle River, NJ: Pearson.

Rhodes, J. E. (2005). A model of youth mentoring. In D. DuBois, \& M. Karcher (Eds.), Handbook of youth mentoring (pp. 30-43). Thousand Oaks, CA: Sage. https://doi.org/ 10.4135/9781412976664.n3

Rhodes, J. E. (2008). Improving youth mentoring interventions through research-based practice. American Journal of Community Psychology, 41, 35-42. https://doi.org/10.1007/ s10464-007-9153-9

Rhodes, J. E., \& DuBois, D. L. (2008). Mentoring relationships and programs for youth. Current Directions in Psychological Science, 17(4), 254-258. https://doi.org/10.1111/ j.1467-8721.2008.00585.x

The ADA National Network. (2016). What is the Americans with Disabilities Act (ADA)? Retrieved from https://adata.org/learn-about-ada

The Social Express. (2016). What is the Social Express? Retrieved from http://thesocialexpress.com

Trout, A. L., Nordness, P. D., Pierce, C. D., \& Epstein, M. H. (2003). Research on the academic status of children with emotional and behavioral disorders: A review of the literature from 1961 to 2000. Journal of Emotional and Behavioral Disorders, 11(4), 198-210. https://doi.org/10.1177/10634266030110040201

U.S. Department of Education. (2016). IDEA Section 618 data products. Retrieved from http://www2.ed.gov/programs/osepidea/618-data/static-tables/index.html

U.S. Department of Justice. (2015). Georgia Network for Educational and Therapeutic Support, D.J. No. 169-19-71. Retrieved from http://www.ada.gov/olmstead/documents/ 
gnets_lof.pdf

Wehby, J. H., Lane, K. L., \& Falk, K. B. (2003). Academic instruction for students with emotional and behavioral disorders. Journal of Emotional and Behavioral Disorders, 11(4), 194-197. https://doi.org/10.1177/10634266030110040101

Wood, Quirk, and Swindle. (2016). Teaching responsible behavior. Developmental therapy-developmental teaching for troubled children and adolescents. Austin, TX: PRO-ED.

\section{Copyright Disclaimer}

Copyright for this article is retained by the author(s), with first publication rights granted to the journal.

This is an open-access article distributed under the terms and conditions of the Creative Commons Attribution license (http://creativecommons.org/licenses/by/3.0/). 